\title{
HOW SOIL-BORNE PATHOGENS MAY AFFECT PLANT COMPETITION
}

\author{
Wim H. Van der Putten and Bas A. M. Peters \\ Netherlands Institute of Ecology, P.O. Box 40, 6666 ZG, The Netherlands
}

\begin{abstract}
A role for pathogens in plant competition has often been suggested, but examples are rare and, in the case of soil pathogens, virtually absent. In this paper we examine if and how soil-borne pathogens may play a role in plant competition. As a model, two successional plant species from coastal sand dunes were used: Ammophila arenaria (marram grass) and Festuca rubra ssp. arenaria (sand fescue). The root zone of A. arenaria contains pathogens that contribute to the degeneration of their host when dunes become stabilized. These pathogens (plant parasitic nematodes and pathogenic fungi) are relatively harmless to the immediate successor $F$. rubra. We tested the hypothesis that $F$. rubra, when grown in a mixed culture with $A$. arenaria, will be favored when $A$. arenaria is exposed to soil-borne pathogens from its own root zone.

In a greenhouse, seedlings of both species were grown in replacement series in sterilized (pathogen-free) and unsterilized (pathogen-containing) soils originating from the root zone of natural $A$. arenaria. Nutrient additions, soil moisture, and the length of the experiment were based on two pilot studies. When exposed to its soil-borne pathogens, A. arenaria was outcompeted, especially when it constituted $<50 \%$ of the planted mixture. Nutrient limitation enhanced the replacement of A. arenaria by $F$. rubra especially in unsterilized soil. This was due to reduced plasticity of $A$. arenaria in responding to nutrient limitation when exposed to its pathogens. The present results support previous suggestions that soil pathogen-driven competition may be an important mechanism in species replacement in coastal foredune vegetation.
\end{abstract}

Key words: allocation; Ammophila arenaria; apparent competition; clonal plants; coastal sand dunes; Festuca rubra ssp. arenaria; fungi; host specificity; nematodes; The Netherlands; plasticity; succession.

\section{INTRODUCTION}

Competition is generally regarded as an important ecological factor structuring the composition and diversity of natural communities in space and time (Grace and Tilman 1990). In many cases, direct competition between two species from the same trophic level will be affected by species from other trophic levels. Herbivores, mutualists, and pathogens should be taken into account when considering competition between plants, but the resulting effect may be difficult to predict (Clay 1990). Holt $(1977,1984)$ presented an example of shifts in relative prey densities mediated by an enemy shared by them, which could not be related to any direct effects between the prey. This was called "apparent competition" (Holt 1977, Connell 1990).

Effects of pathogens have been mentioned in recent literature on plant competition (Clay 1990, Louda et al. 1990), although few examples are presented. This is most likely due to a rather recent interest of ecologists in pathogens as a structuring force in natural vegetation (Burdon 1987). Although Clements (1928) suggested pathogens were involved in changes in the composition of natural vegetation, most examples still originate from the last decade or two (Dobson and Crawley

Manuscript received 11 March 1996; revised 17 October 1996; accepted 4 November 1996.
1994). The majority of these studies concern pathogens that parasitize the aerial parts of plants (e.g., Burdon 1982, 1987, Burdon et al. 1984, De Nooij 1987, Augspurger 1989, Paul 1989, Linders 1994, Castello et al. 1995, Jarosz and Davelos 1995) and refer to a variety of habitats. Very few of these examples on aboveground pathogens, however, concern competition within (Burdon et al. 1984) or between plant species (Paul 1989).

There are fewer examples of soil-borne pathogens in natural vegetation than of aboveground pathogens and their effects on plant competition have not yet been demonstrated. Studies on soil-borne pathogens in natural vegetation are mainly confined to coastal sand dunes (Oremus and Otten 1981, Van der Putten et al. 1993, Zoon et al. 1993, De Rooij-Van der Goes et al. $1995 a, b)$, tropical rain forests (Augspurger 1990), and old fields (Bever 1994). The presence of specific soil pathogens in a successional sere of plants in coastal sand dunes (Van der Putten et al. 1993) should have consequences for competitive interactions among the successive plant species (Crawley 1993). In soybean (Glycine max) the soybean cyst nematode (Heterodera glycines) reduced the competitiveness of its host against the weed common lambsquarters (Chenopodium album) (Chen et al. 1995). This example, although originating from agriculture, supports the hypothesis 
that soil pathogens may be involved as an indirect factor in interspecific plant competition.

The present study tested the hypothesis that specific soil-borne pathogens affect competitive interactions between plant species. Because effects of soil pathogens on plant competition were not significant in studies of Bever (1994) or in our pilot experiments, the focus of the present work is the influence of experimental conditions affecting the role of soil-borne pathogens in plant competition.

As a model we used the replacement of Ammophila arenaria by Festuca rubra ssp. arenaria, representing one of the first successional stages in coastal sand dunes of northwestern Europe. At sites near the beach, where plants are regularly buried by wind-blown sand, $A$. ar enaria dominates the vegetation, as no other plant is able to survive such extreme conditions (Ranwell 1958). More landward, where both the rate and amount of sand accretion diminish, the vigor of $A$. arenaria declines (Marshall 1965, Hope-Simpson and Jefferies 1966, Huiskes 1979, Willis 1989) and Festuca rubra ssp. arenaria takes over dominance in the vegetation (Anderson and Taylor 1979, Huiskes 1979). Plant-parasitic nematodes and pathogenic fungi in the root zone of A. arenaria are implicated in this degeneration (Van der Putten et al. 1988, 1990, De Rooij-Van der Goes 1995, De Rooij-Van der Goes et al. 1995a, $b$ ) and $F$. rubra is relatively tolerant to the pathogens of its predecessor (Van der Putten et al. 1993).

According to our hypothesis, A. arenaria will be less competitive against $F$. rubra ssp. arenaria when grown in unsterilized sand from its own root zone than in this sand after sterilization. As a result, A. arenaria will be relatively less productive in mixtures with $F$. rubra ssp. arenaria in unsterilized than in sterilized soil from its own root zone. The hypothesis was tested by three greenhouse experiments. Two were pilots to study effects of nutrients and soil moisture on initial growth conditions. The results from these experiments were used to choose nutrient and soil moisture conditions for the competition experiment. An unfertilized control was included to examine whether the applied nutrient solution masks effects of mutualists, such as mycorrhizal fungi.

\section{Methods}

\section{Sampling and treatment of the soil}

At the coastal foredune of Voorne, The Netherlands, soil samples were collected from the upper $30-\mathrm{cm}$ soil layer of a site near Haringvlietdam $\left(51^{\circ} 52^{\prime} \mathrm{N}, 4^{\circ} 4^{\prime} \mathrm{E}\right)$ covered by a monospecific stand of $A$. arenaria. Just landward of this successional stage, F. rubra ssp. arenaria (hereafter called $F$. rubra) started to invade the vegetation. The site was subject to annual burial by 20-30 cm of wind-blown sand (Van der Putten et al. 1989), so that the collected soil contained mainly 1-yrold roots of $A$. arenaria.
For each experiment ( $1 \mathrm{~A}, \mathrm{~B}$, and 2$), \approx 300 \mathrm{~kg}$ of soil was randomly collected from an area of $200 \times 10 \mathrm{~m}^{2}$. The samples for experiment $1 \mathrm{~A}$ were collected in the autumn of 1991, for 1B in winter 1991-1992, and for Experiment 2 in winter 1992-1993. The soil samples were sieved (1-cm mesh) and coarse fractions such as shells, rhizomes, and roots were removed. The roots were chopped into $1-\mathrm{cm}$ lengths and mixed throughout the sand, so that for each sampling event a bulk sample was obtained. Half of each bulk sample was sterilized by gamma-irradiation (40 kGy). The percentage soil moisture was analyzed by drying subsamples for $48 \mathrm{~h}$ at $105^{\circ} \mathrm{C}$.

\section{Collecting, growing, and harvesting of plants}

Spikes of A. arenaria and F. rubra were collected from the outer dunes at Voorne. The spikes were dried and threshed manually. The caryopses were stored at $4^{\circ} \mathrm{C}$ until needed. The seeds were germinated in growth chambers set at $30^{\circ} \mathrm{C}$ in the light period of the photocycle $(8 \mathrm{~h})$ and $20^{\circ} \mathrm{C}$ in dark $(16 \mathrm{~h})$.

Pots (10 cm high and $1.5 \mathrm{~L}$ in all experiments) were filled with an amount of sand of a moisture content as specified for each experiment. The pots were covered by tinfoil to prevent the sand from desiccating. Uniform seedlings with a shoot length of 3-5 cm were selected and planted in the pots. The pots were placed in a greenhouse in random arrangement (average temperature $23^{\circ} \pm 2^{\circ} \mathrm{C}$ ) and illumination (Philips HPIT 400 W) was supplied as necessary to maintain a 16:8 light: dark photocycle. The position of the pots in the greenhouse was changed twice a week by rotation to avoid interference by possible local climatic differences. Soil moisture content was reset at the specified percentage by supplying demineralized water weekly or (when plants used more water) twice a week. Hoagland nutrient solution (Hewitt 1966) was supplied weekly at rates specified for each experiment. At harvest, the plant material was dried for $48 \mathrm{~h}$ at $70^{\circ} \mathrm{C}$. In Experiment 2 , the root material of the two plant species could not be separated.

\section{Pilot studies}

Nutrient additions (Expt. 1A).--In October-November of 1991, the effect of nutrient supply on initial growth of $A$. arenaria and $F$. rubra was investigated in sterilized (pathogen-free), as well as unsterilized (pathogen-containing) soil originating from the monospecific stand of $A$. arenaria. The pots contained 1300 $\mathrm{g}$ of sand on a dry mass basis and $10 \%$ soil moisture (mass/mass). Three nutrient levels were applied: none, low, and high. The low nutrient level was: $12 \mathrm{~mL} /$ pot of strength 1 Hoagland solution in weeks 1 and 2, and $25 \mathrm{~mL} /$ pot in weeks 3-6. The high nutrient supply was three times the low one. Each treatment was repeated six times, so that the total experimental design included 2 (species) $\times 2$ (soil sterilization) $\times 3$ (nutrient supply) 
$\times 6$ (replications $)=72$ pots. The plants were harvested after $6 \mathrm{wk}$.

Soil moisture (Expt. 1B).--In February-March of 1992, the effect of soil moisture on growth of A. arenaria and $F$. rubra was studied in sterilized (pathogenfree) and unsterilized (pathogen-containing) soil from the root zone of the monospecific stand of $A$. arenaria. The pots were filled with $1430 \mathrm{~g}$ of sand (on a dry mass basis) at three soil moisture levels: 5, 10, and $15 \%$ (mass/mass). The indicated percentages are maximum values, as soil moisture was reset once or (in the second half of the experiment) twice a week. Each treatment was repeated five times, so that the experimental design involved 2 (species) $\times 2$ (soil sterilization) $\times 3$ (maximum soil moisture percentages) $\times 5$ (replications) $=60$ pots. Nutrient solution was applied as follows: $12 \mathrm{~mL} /$ pot strength 0.5 Hoagland (weeks 1 and 2), $25 \mathrm{~mL} /$ pot strength 1 (weeks 3-4), and 50 $\mathrm{mL} /$ pot strength 1 (weeks 5-6). The plants were harvested after $6 \mathrm{wk}$.

\section{Replacement experiment with A. arenaria and F. rubra (Expt. 2)}

In February 1993, competition between A. arenaria and $F$. rubra was examined in relation to soil-borne pathogens of $A$. arenaria. A replacement series according to De Wit (1960) was applied with 8/0, 6/2, 4/ $4,2 / 6$, and $0 / 8$ seedlings of $A$. arenaria/F. rubra per pot in sterilized and unsterilized soils.

Based on the pilot Experiment 1B, soil moisture was set at $10 \%$. At the start, the pots contained $1360 \mathrm{~g}$ of soil on dry mass basis and the soil moisture was reset initially weekly but later twice per week. The nutrient supply was $12 \mathrm{~mL} /$ pot during weeks 1 and 2, $25 \mathrm{~mL} /$ pot during weeks 3 and 4 , and $50 \mathrm{~mL} /$ pot during the remaining weeks (all of strength 1 Hoagland solution). This supply rate, therefore, approached the low rate of Experiment 1A. Plants were harvested after 7, 11, and $16 \mathrm{wk}$.

Each treatment was repeated five times, so that the experiment included 5 (plant mixtures) $\times 2$ (soil sterilization) $\times 3$ (harvests) $\times 5$ (replicates $)=150$ pots In Experiment 1, productivity in unsterilized soil differed significantly between the fertilized and unfertilized treatments. Therefore, another 50 pots were included ( 5 plant mixtures $\times 2$ soil sterilization treatments $\times 5$ replications) receiving no fertilization. These plants were harvested after 16 wk of growth.

Characterization of soil fungi and nematodes.-At harvest, fungi were isolated from the soil in the pots by plating soil dilutions $\left(10^{-2}-10^{-5}\right)$ in triplicate on malt-peptone extract agar (20 g/L malt extract (Oxoid), $3 \mathrm{~g} / \mathrm{L}$ peptone (Oxoid), $15 \mathrm{~g} / \mathrm{L}$ agar (Merck), $100 \mathrm{mg} / \mathrm{L}$ validamycine (Solacol), Aagrunol (Gams and Van Laar 1982), and $50 \mathrm{mg} / \mathrm{L}$ oxytetracycline).

After incubating at $23^{\circ} \mathrm{C}$ for $4-7 \mathrm{~d}$, the fungi were subcultured on potato dextrose agar (Oxoid) and identified according to Domsch et al. (1980), except $F u$ - sarium species, which were identified according to Nelson et al. (1983). Nematodes from roots were extracted by Baermann funnels ('s Jacob and Van Bezooijen 1984) and from soil by decanting whole pots (Oostenbrink 1960). Nematodes were identified to genus level according to Bongers (1988).

\section{Data analysis}

Data were analyzed by means of analysis of variance (ANOVA). If necessary according to Cochran's test ( $P$ $<0.05$ ), data were transformed to a logarithm, a square root, or an arcsine of the square root in order to obtain homogeneity of variances. Treatment means were compared by Tukey's hsd [honestly significant difference] test with $P<0.05$ (Sokal and Rohlf 1981).

Shoot biomass per plant was calculated for each species by dividing the plant's total shoot biomass by the number of plants of the corresponding species in the mixture. Root biomass ratios (RBR) were calculated as root dry biomass divided by the total dry biomass. The relative yield of shoots (RYS) was calculated as O/M; $\mathrm{O}=$ productivity of a species in a mixture and $\mathrm{M}=$ production of the same species in the monoculture. The Relative Yield Total of shoots (RYTS) was calculated as $\mathrm{O} 1 / \mathrm{M} 1+\mathrm{O} 2 / \mathrm{M} 2$, where $1,2=$ different species. This calculation is according to the RYT-definition given by De Wit and Van den Bergh (1965). As the RYS and RYTS are based on treatment averages, the effects could not be tested statistically.

\section{RESUlts \\ Pilot studies}

Nutrient additions (Expt. 1A).-When subjected to different nutrient additions, Ammophila arenaria in all cases produced significantly more dry matter in sterilized than in unsterilized soil (Fig. 1). Biomass production of Festuca rubra was also significantly increased by soil sterilization. However, when the biomass production in unsterilized soil was related to the sterilized soil, F. rubra showed less growth reduction (63\% when unfertilized and 40-28\% when supplied with the low and high amount of nutrients, respectively) than A. arenaria (73\% when unfertilized and 63$51 \%$ when supplied with the low and high amount of nutrients, respectively).

In both sterilized and unsterilized soils, the total productivity of $A$. arenaria and $F$. rubra was significantly higher when supplied with nutrients at the low rate than with none (Fig. 1). Further nutrient additions did not affect productivity significantly, although $A$. arenaria showed a positive trend in unsterilized soil.

The data for the production of shoot dry matter of both plant species were generally in accordance with those of the total biomass, although root production was not significantly enhanced by an increased supply of nutrients (data not shown). The root/total biomass ratios (RBR) of both plant species were lowest in fer- 


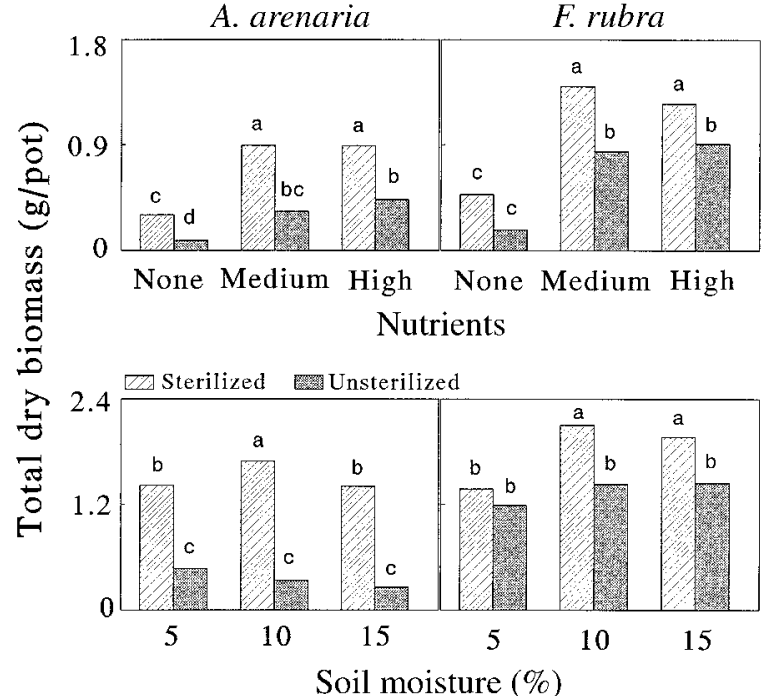

Fig. 1. Pilot experiments. Total dry biomass of Ammophila arenaria and Festuca rubra monocultures in sterilized and unsterilized soil from the root zone of natural A. arenaria at three rates of nutrient supply (Expt. 1A) and three levels of soil moisture (Expt. 1B). Different letters indicate significant differences $(P<0.05)$ within each plot.

tilized soils. F. rubra changed allocation pattern in both sterilized and unsterilized soil in response to nutrient limitation, resulting in a higher root/total biomass ratio (RBR) in both sterilized and unsterilized soils (Table 1). A. arenaria, however, could only change allocation to roots effectively when grown in sterilized soil. In unsterilized soil, the ability of $A$. arenaria to respond to nutrient limitation was apparently constrained (Table $1)$. In the fertilized soils, $F$. rubra produced rhizomes, but there were no significant differences among treatments (data not shown).

Soil moisture (Expt. 1B).-Within the range of 5$15 \%$ soil moisture, total productivity of A. arenaria was significantly increased by soil sterilization (Fig. 1). In sterilized soil, the plants produced more total biomass at $10 \%$ soil moisture than at 5 or $15 \%$. In unsterilized soil, there was a trend, although not significant, of decreasing productivity with increasing soil moisture. Root production tended to be reduced more than shoot production when soil moisture increased (data not shown), but this did not lead to significant differences in RBR (Table 1).

Productivity of $F$. rubra was also stimulated by soil sterilization, but less than $A$. arenaria. Significant effects appeared at 10 and $15 \%$ soil moisture (Fig. 1). Rhizome production (data not shown) and the RBR were not affected by soil sterilization or soil moisture (Table 1).

\section{Replacement experiment with A. arenaria and F. rubra (Expt. 2)}

With nutrient addition.-In sterilized and unsterilized soil, the shoots of both plant species in monocul-
TABLE 1. Root/total biomass ratios (RBR) in the pilot experiments on the effects of nutrients (1A) and soil moisture (1B) of monocultures of Ammophila arenaria and Festuca rubra in sterilized (S) and unsterilized (NS) sand from $A$. arenaria's root zone. Within each treatment (nutrients, moisture) and plant species, significant differences $(P<$ 0.05 ) according to Tukey's hsd test are indicated by different superscript letters.

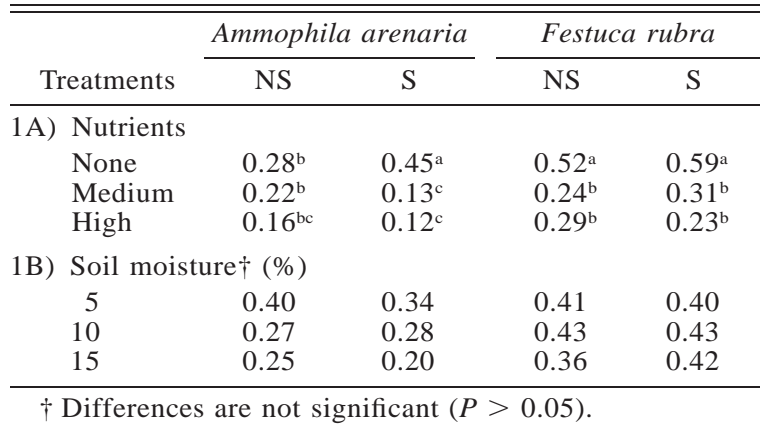

tures generally contributed to more than half of the total dry matter (Fig. 2). In sterilized soil, A. arenaria produced significantly more shoot and root dry matter than in unsterilized soil. Root productivity of $F$. rubra was also significantly higher in sterilized than in unsterilized soil at all harvests. However, F. rubra only produced significantly more shoot biomass in sterilized

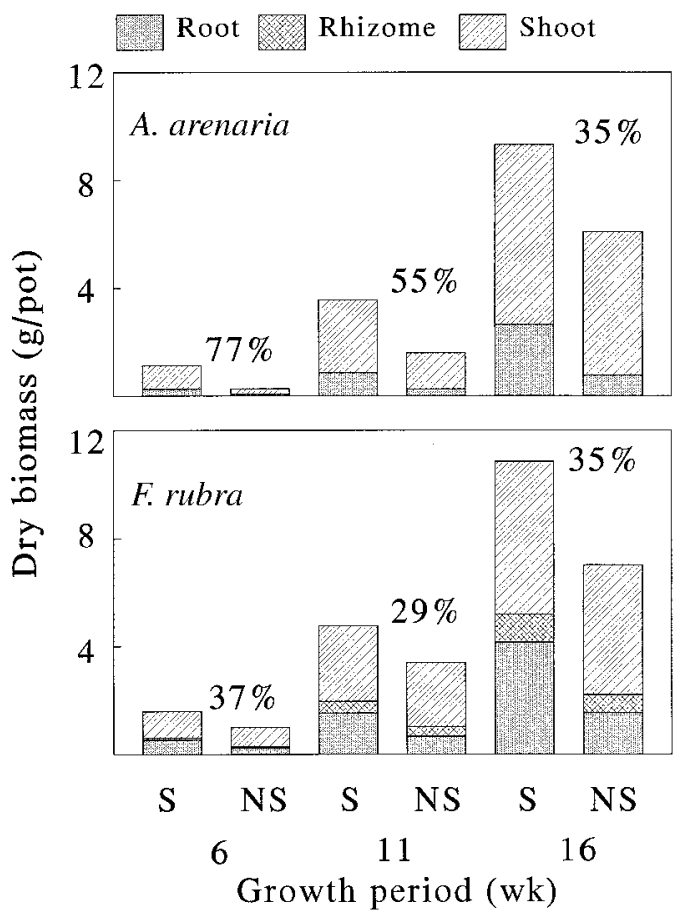

FIG. 2. Dry biomasses of Ammophila arenaria and Festuca rubra shoots, rhizomes, and roots when grown as monocultures in sterilized (S) and unsterilized (NS) soil from the root zone of A. arenaria at three harvest dates, i.e., after 6 , 11, and 16 wk of growth (Expt. 2). Percentage growth reduction in unsterilized soil as compared to sterilized soil is given above each pair of bars. 


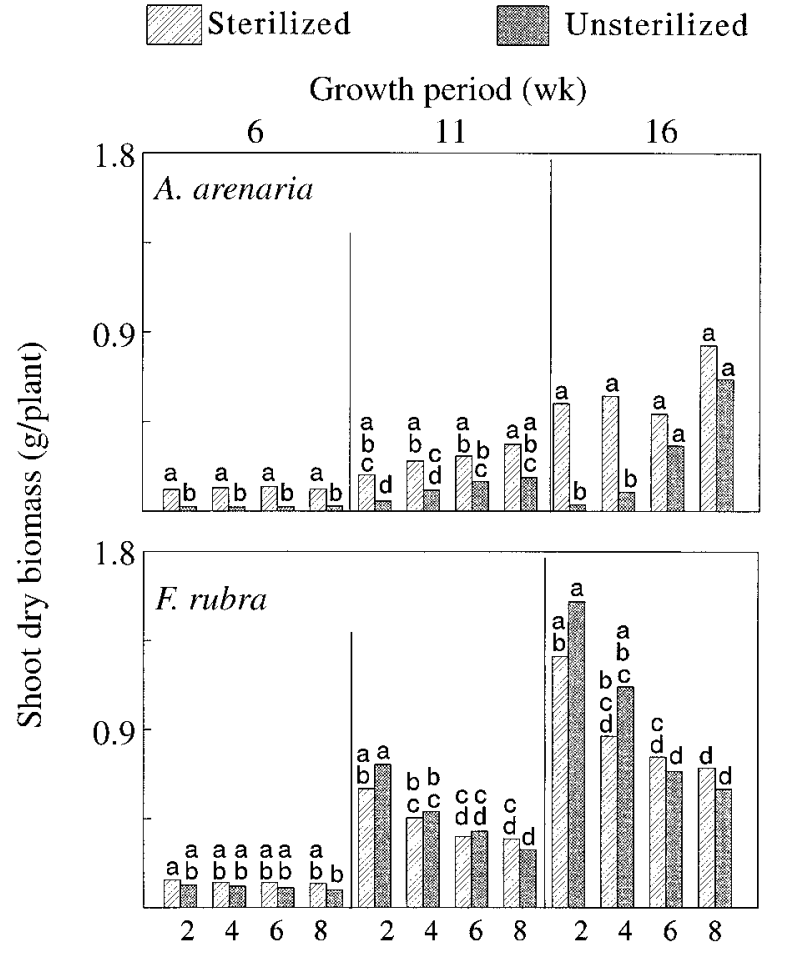

No. plants per species in mixture

FIG. 3. Average shoot biomasses per plant of Ammophila arenaria and Festuca rubra in monocultures, as well as in the different mixtures on sterilized and unsterilized soil from the root zone of A. arenaria at three successive harvest dates, i.e., after 6, 11, and 16 wk of growth (Expt. 2). Significant differences within each plot are indicated by different letters.

than in unsterilized soil at the first harvest $(P<0.05$; results of Tukey hsd tests not shown). At the final harvest rhizome biomass was significantly higher in the sterilized than in the unsterilized soil.

In the monocultures, production in nonsterilized soil was always less than in sterilized soil. At the first harvest, $A$. arenaria growth was reduced much more than growth of $F$. rubra (77\% vs. $37 \%$, Fig. 2). At the final harvest, both plant species showed a similar growth reduction in the unsterilized soil $(35 \%)$.

The competition experiment lasted longer than the pilot studies and as a result the root systems of $A$. arenaria and $F$. rubra could not be separated during the later harvests. The shoot/root ratio of the monocultures might have been used to assess the root production of individual species in the mixtures. However, since this ratio has not been proven to remain constant over a range of replacement series, only the results from shoots are presented.

At the first harvest of species mixtures, the shoot biomasses per plant of $A$. arenaria were significantly reduced in unsterilized as compared to sterilized soil (Fig. 3). Within sterilized or unsterilized soils, no differences of shoot biomass per plant occurred among the treatments with different ratios of $A$. arenaria/F. rubra. Within each of the mixtures, the shoot biomass per plant of $F$. rubra was not significantly affected by soil sterilization, although there was a trend that individual shoots weighed less in pots with eight than with two F. rubra plants (Fig. 3).

At harvests 2 and 3, in sterilized soil the shoot biomass per plant of $A$. arenaria did not become significantly different among the A. arenaria/F. rubra replacement gradient. In unsterilized soils, however, the shoot biomass per plant was positively related to the number of $A$. arenaria individuals in the mixture. At harvest 3 , in the mixtures with eight and six A. arenaria plants, individual shoot biomasses of $A$. arenaria were significantly higher than in the mixtures with two and four A. arenaria plants. Moreover, at both harvests 2 and 3 in the mixtures dominated by A. arenaria, there were no significant differences in individual shoot biomasses between plants from sterilized and unsterilized soils (Fig. 3). In the mixtures with two or four A. arenaria plants, on the other hand, the individual shoot biomasses of A. arenaria grown in sterilized soil remained to be significantly higher than in unsterilized soil. F. rubra, on the other hand, showed a reverse pattern. At later harvests, the lower the number of plants of this species, the higher the shoot biomass per plant (Fig. 3). This development occurred in both unsterilized and sterilized soils.

At the first harvest, soil sterilization significantly increased total shoot production of A. arenaria in the monoculture, as well as in the mixtures (Fig. 4A). At the second harvest, significant effects were seen only with eight or six plants per pot of A. arenaria (Fig. 4B). The reverse picture emerged from the third harvest, where the increased productivity due to sterilization was only significant for the lower plant densities (Fig. 4C). Shoot production of F. rubra was increased by soil sterilization at the first harvest when grown as a monoculture (Fig. 4A). Thereafter, the total shoot production did not significantly respond to soil sterilization (Fig. 4B, C). At the lower contribution of $F$. rubra to the planted mixture, its shoot production in unsterilized soil tended to be even higher than in sterilized soil.

During the course of the experiment, the A. arenarial $F$. rubra replacement ratio that showed equal productivity for both species, remained fairly constant at $>6 / 2$ in unsterilized soils (Fig. 4A-C). In the sterilized soils, however, this ratio shifted from about $4 / 4$ to almost $6 / 2$ between the first and final harvest. Thus, if the amount of produced biomass is indicative of the intensity of competition, in fertilized pots $F$. rubra was outcompeting $A$. arenaria in both unsterilized and sterilized soil.

When the shoot productivity values were calculated as relative yields, the plant densities at which equal relative productivity values were obtained were similar for both sterilized and unsterilized soils (Fig. 4D-F). 

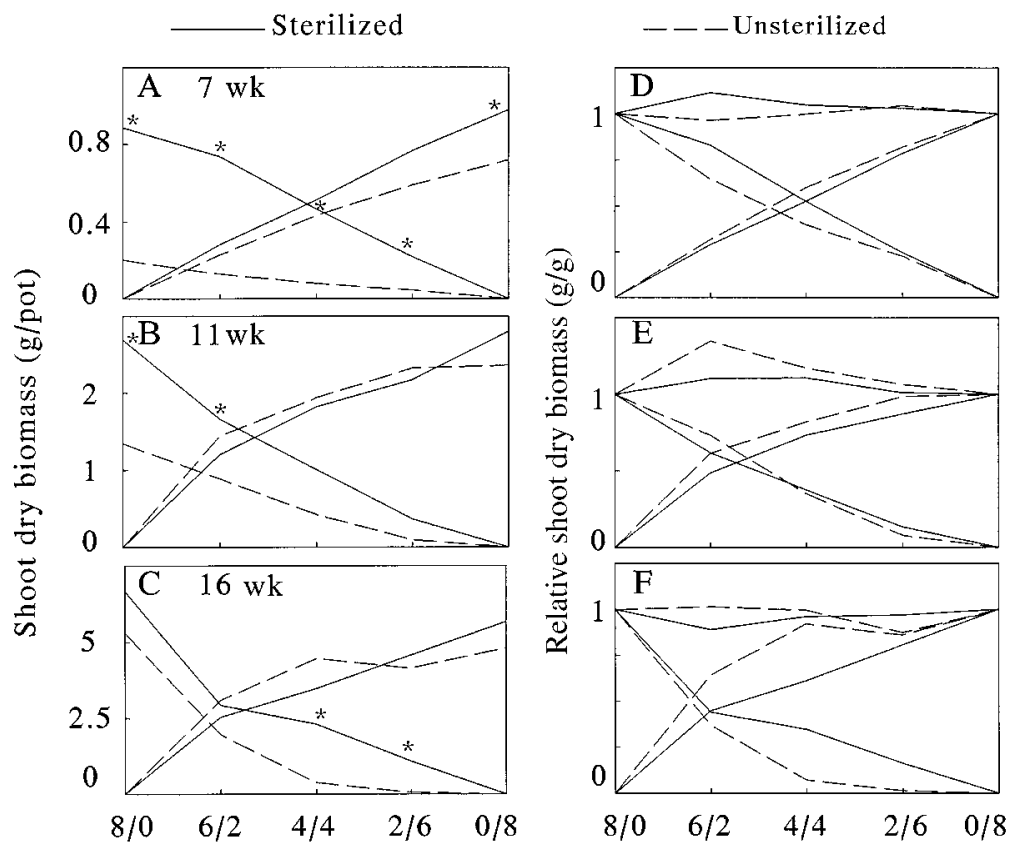

No. Ammophila arenaria/Festuca rubra in mixture

FIG. 4. Fertilized treatments (Expt. 2). Shoot dry biomasses and relative shoot dry biomasses of Ammophila arenaria and Festuca rubra shoots when grown both in monocultures and in mixtures in sterilized and unsterilized soil from the root zone of A. arenaria after three periods of growth. In parts A-C, asterisks indicate significant differences between sterilized and unsterilized soils. In parts D-F, relative yield totals of shoots are shown as well (upper two curves).

According to the relative yields the intensity of competition in both sterilized and unsterilized soils increased in time as the replacement ratio showing equal production for both species shifted from $4 / 4$ to $6 / 2$ plants of $A$. arenaria/F. rubra.

No nutrient addition.-After $16 \mathrm{wk}$, when no nutrients were added, the shoot biomasses of A. arenaria and $F$. rubra in both monocultures and mixtures were in the same range as the fertilized plants after $11 \mathrm{wk}$ (cf. Fig. 5A and Fig. 4B). Without nutrient addition, shoot productivity of $F$. rubra was not affected at all by soil sterilization, whereas shoot production of $A$. arenaria was always higher in the sterilized than in the unsterilized soil (Fig. 5A; difference not significant in the monoculture). As in the second harvest of the fertilized plants (Fig. 4B), the A. arenaria/F. rubra replacement ratio showing equal shoot productivity was higher for the unsterilized than for the sterilized soil (Fig. 5A). The relative shoot yields of the unfertilized plants $16 \mathrm{wk}$ old, on the other hand, were more comparable to those of the fertilized plants of the same age (cf. Fig. 5B and Fig. 4F).

However, in the unfertilized treatment there was a larger difference between unsterilized and sterilized soils for the plant densities at which equal shoot production was obtained than in the case of plants supplied with nutrients (Fig. 5B vs. 4F). In the sterilized soil, the plant densities leading to equal productivity were close to mixtures with four plants of each species, which implies a near absence of interspecific competition.

The allocation of biomass to roots (RBR) of monocultures of both $A$. arenaria and $F$. rubra depended on a combination of nutrient supply and soil sterilization (Table 2). When nutrients were supplied, the RBRs of both species were significantly lower in unsterilized than in sterilized soil. Nutrient limitation stimulated the allocation of biomass to roots. For unfertilized $F$. rubra, the RBRs in sterilized and unsterilized soils were not different. The RBR of unfertilized A. arenaria, however, was significantly lower in unsterilized than in sterilized soil.

The root biomasses of monocultures of both species were also affected by a combination of soil sterilization and nutrient supply (Table 2 ). In sterilized soil, A. arenaria and $F$. rubra produced more root biomass with nutrient supply than without, whereas in unsterilized soil no significant difference appeared. Thus far, the plant species reacted similarly, however, specific differences emerged when the root biomasses were related to each other. When supplied with nutrients, F. rubra produced 1.5 times as much root biomass as $A$. arenaria when grown in sterilized soil and 2 times as much when unsterilized. However, without supply of nutrients the relative differences between both species in sterilized and unsterilized soils were considerably larger. In ster- 

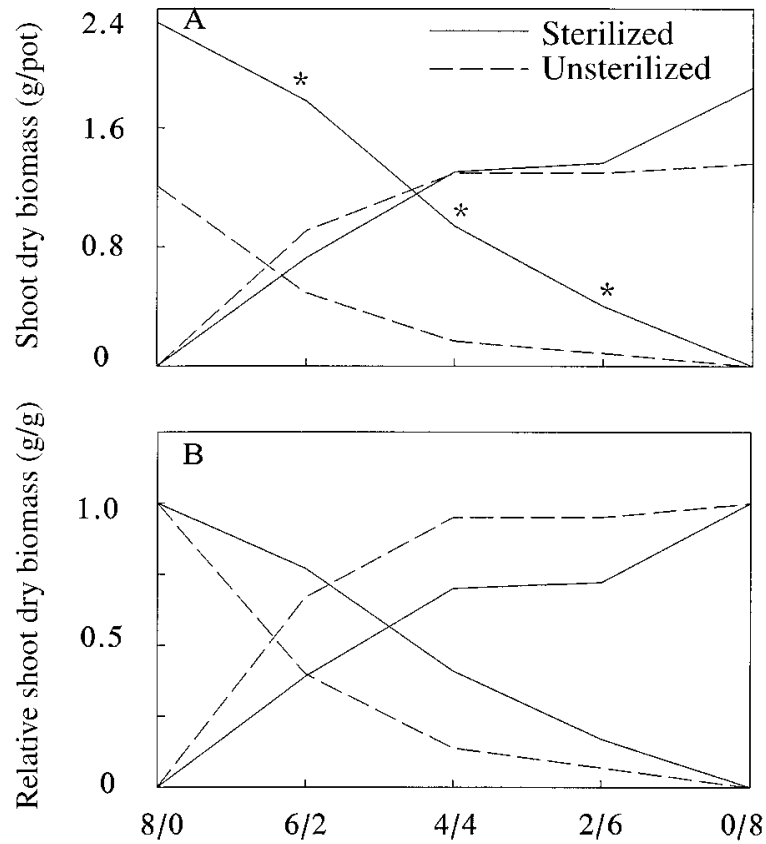

No. Ammophila/Festuca in mixture

FIG. 5. Unfertilized treatments (Expt. 2). Shoot dry biomasses and relative shoot dry biomasses of Ammophila arenaria and Festuca rubra shoots when grown both in monocultures and in mixtures in sterilized and unsterilized soil from the root zone of $A$. arenaria after three periods of growth. In part A, asterisks indicate significant differences between sterilized and unsterilized soils. ilized soil, F. rubra produced 1.3 times as much, and in unsterilized soil, 3 times as much root biomass as A. arenaria. These findings confirm the observations in the pilot study and show that soil-borne pathogens reduce the plasticity of the response of $A$. arenaria to nutrient limitation.

Characterization of soil fungi and nematodes.Characterization of the nematode and fungal community in the pots with fertilized monocultures of $A$. arenaria and $F$. rubra was carried out to elucidate the possible origin of the specific growth reduction of $A$. arenaria in soil collected from its own root zone. Nematode species that could be recovered from roots of $A$. arenaria, but not from $F$. rubra, were: the endoparasitic Pratylenchus sp. and Rotylenchus sp., as well as the sedentary endoparasites Meloidogyne sp. (larvae), and Heterodera sp. (both cysts and males) (Table 3). The ectoparasitic Telotylenchus ventralis only occurred in soil from pots with monocultures of A. arenaria, whereas Tylenchus sp. was found in roots of $F$. rubra but not in roots of $A$. arenaria. The remaining nematodes (though all identified to the genus level) occurred in either soil or soil and roots of monocultures of both plant species. Specificity of plant parasitic nematodes, therefore, was correlated mainly to endoparasitic or sedentary endoparasitic nematodes or the ectoparasitic Telotylenchus ventralis (recently renamed as Tylenchorhynchus ventralis).

Soil fungi specific for monocultures of A. arenaria were Apiospora montagne, Alternaria alternata, Chrysosporium pannorum, Cylindrocarpon dydimum, and Fusarium equisetum. Soil fungi specific for monocul-

TABLE 2. Root biomasses, root/total dry biomass ratios (RBR), and the corresponding $F$ values after ANOVA of Ammophila arenaria and Festuca rubra monocultures in sterilized (+) and unsterilized (-) soil, both fertilized (+ nutrients) and unfertilized (- nutrients), at harvest 3 of Expt. 2. Within columns, different superscript letters following the ratios identify significant differences $(P<0.05)$.

\begin{tabular}{|c|c|c|c|c|c|}
\hline \multicolumn{6}{|l|}{ Data summary } \\
\hline \multicolumn{2}{|c|}{ Treatment } & \multicolumn{2}{|c|}{ A. arenaria } & \multicolumn{2}{|c|}{ F. rubra } \\
\hline Nutrients & $\begin{array}{l}\text { Sterili- } \\
\text { zation }\end{array}$ & $\begin{array}{c}\text { Root } \\
\text { biomass }\end{array}$ & RBR & $\begin{array}{c}\text { Root } \\
\text { biomass }\end{array}$ & RBR \\
\hline+ & + & $2.66^{\mathrm{a}}$ & $0.21^{\mathrm{b}}$ & $4.15^{\mathrm{a}}$ & $0.48^{\mathrm{a}}$ \\
\hline+ & - & $0.77^{\mathrm{c}}$ & $0.13^{c}$ & $1.55^{\mathrm{b}}$ & $0.30^{\mathrm{b}}$ \\
\hline- & + & $1.65^{\mathrm{b}}$ & $0.42^{\mathrm{a}}$ & $2.11^{\mathrm{b}}$ & $0.57^{\mathrm{a}}$ \\
\hline
\end{tabular}

ANOVA table

\begin{tabular}{|c|c|c|c|c|c|}
\hline \multirow[b]{3}{*}{ Treatment } & \multirow[b]{3}{*}{ df } & \multicolumn{4}{|c|}{$F$ values } \\
\hline & & \multicolumn{2}{|c|}{ A. arenaria } & \multicolumn{2}{|c|}{ F. rubra } \\
\hline & & $\begin{array}{c}\text { Root } \\
\text { biomass }\end{array}$ & RBR & $\begin{array}{c}\text { Root } \\
\text { biomass }\end{array}$ & RBR \\
\hline Nutrients (N) & 1 & $24.3 * * *$ & $129 * * *$ & $15.6 * *$ & $40.9 * * *$ \\
\hline Sterilization $(\mathrm{S})$ & 1 & $143 * * *$ & $142 * * *$ & $37.3 * * *$ & $10.7 * *$ \\
\hline $\mathrm{N} \times \mathrm{S}$ & 1 & $9.7 * *$ & $11.3 * *$ & $15.1 * *$ & $10.7 * *$ \\
\hline Error (mean squares) & 13 & 0.079 & 0.0018 & 0.336 & 0.053 \\
\hline
\end{tabular}

\footnotetext{
** $P<0.01 ; * * * P<0.001$.
} 
TABLE 3. Densities of nematodes (inds./100 g soil [mean $\pm 1 \mathrm{sD}$ ]; $N=5$ ) present in soil used for Experiment 2, prior to planting. Overall recoveries during harvests 1 and 2 are presented as + (recovered) and - (not recovered) for both soil and roots of Ammophila arenaria and Festuca rubra monocultures; $++=$ densities $>100$ inds./100 g soil; nd $=$ not determined.

\begin{tabular}{|c|c|c|c|c|c|}
\hline \multirow[b]{3}{*}{ Nematode species } & \multirow[b]{3}{*}{ Initial numbers } & \multicolumn{4}{|c|}{ Recovery at first and second harvests } \\
\hline & & \multicolumn{2}{|c|}{ Ammophila arenaria } & \multicolumn{2}{|c|}{ Festuca rubra } \\
\hline & & Soil & Roots & Soil & Roots \\
\hline Pratylenchus sp. & $0.07 \pm 0.15$ & - & + & - & - \\
\hline Rotylenchus sp. & $2 \pm 4.29$ & + & + & + & - \\
\hline Tylenchus sp. & $2.7 \pm 0.58$ & + & - & + & + \\
\hline Telotylenchus ventralis & $1.1 \pm 0.55$ & + & - & - & - \\
\hline Heterodera sp. (larvae) & $2.1 \pm 1.79$ & + & + & + & + \\
\hline Heterodera sp. (cysts) & nd & nd & + & nd & - \\
\hline Meloidogyne sp. (larvae) & $3.6 \pm 2.53$ & + & + & + & - \\
\hline Heteroderidae (males) & $0.67 \pm 0.24$ & + & + & + & - \\
\hline Criconematidae & 0 & + & - & - & - \\
\hline Aphelenchus sp. & $1.6 \pm 0.8$ & + & - & + & - \\
\hline Dorylamidae & $18.7 \pm 0.99$ & ++ & + & ++ & + \\
\hline Saprobiotic species & $95.2 \pm 20.9$ & ++ & + & ++ & + \\
\hline
\end{tabular}

tures of $F$. rubra were Acremonium fusidoides, A. strictum, Chaetomium fimeti, and Plectosphaerella сисcumensis. More than 10 species were found in soil from both plant species (species names not listed).

\section{DISCUSSION}

The replacement experiment in sterilized and unsterilized soils from a natural $A$. arenaria root zone demonstrated that soil-borne pathogens of A. arenaria may affect the competitive characteristics of their host when grown in a mixed culture with the immediate successor $F$. rubra. These results support our hypothesis and suggestions of Van der Putten et al. (1993) and Crawley (1993) that the specific soil-borne plant pathogens occurring in coastal foredunes may affect plant competition. The effects of competition were found to depend on the length of the experiment and on the supply of nutrients.

The replacement design is not appropriate for discriminating inter- and intraspecific effects because of its inability to determine density-dependent interactions (Inouye and Schaffer 1981, Firbank and Watkinson 1985, Snaydon 1994). In the present experiment, there may have been two density-dependent effects. One is that the effect of soil pathogen pressure per $A$. arenaria plant may have been inversely related to the number of A. arenaria plants in the mixtures. However, in the early phase of the replacement experiment, soilborne pathogens were the only cause of reduced growth of A. arenaria. When after $6 \mathrm{wk}$ individual shoot biomasses were compared among the various mixtures of the replacement series, no differences could be found between plants from pots with $100 \%$ or $25 \%$ A. arenaria. As at that moment average shoot yields per plant were not different among mixtures in either sterilized or sterilized soil, therefore not suggesting any effect of competition, a density-dependent effect of the soil-borne pathogens on their host plant A. arenaria did not seem to occur.

When the experiment proceeded, the significance of biomass differences between average shoot biomasses from sterilized and unsterilized soil disappeared when the pots contained $100 \%$ or $75 \%$ A. arenaria. The recovery of $A$. arenaria at the end of the growth period has been observed under similar conditions by Van der Putten et al. (1988). However, it did not occur when the plants were grown outdoors in larger experimental units with sterilized and unsterilized root zone soil (Van der Putten et al. 1988, Van der Putten and Troelstra 1990). Nevertheless, in the present experiment in mixtures with $50 \%$ or $25 \%$ A. arenaria, the growth reduction of this species in unsterilized soil remained significant and the relative difference with sterilized soil increased as compared to the monoculture or the mixture with $75 \%$ A. arenaria. Therefore, it is clear that the soil-borne pathogens influenced plant competition, although additive studies are needed to distinguish inter and intraspecific effects from each other.

Growth reduction of $A$. arenaria in unsterilized soil when contributing $25 \%$ or $50 \%$ to the planted mixture occurred in both fertilized and unfertilized pots. However, the difference between species densities in sterilized and unsterilized soil at which equal relative shoot yields occurred was in the latter. Therefore, competition seemed to be enhanced when the plants were exposed to both soil-borne pathogens and nutrient limitation. This was found to be due to the reduction of plasticity of allocation to roots by $A$. arenaria caused by the soil pathogens. As a result, $F$. rubra produced relatively more root biomass than $A$. arenaria, which may have enhanced its ability to compete.

Generally, nutrient limitation may often occur during the early stages of primary succession (Tilman 1982), so that soil pathogens, where they occur, may be ex- 
pected to have a large impact in early primary successions. In coastal foredunes, competition for light is generally supposed to start when shrubs, such as Hippophä rhamnoides invade derelict stands of A. arenaria (Olff et al. 1993). In the present experiments, light was not expected to be limiting, as both plant species produced sparse shoots, A. arenaria being taller than $F$. rubra.

The results obtained from the pot trials may, of course, not be directly extrapolated to the field situation, but they provide an insight into the possible interactions between two successional plants, their soil biota and abiotic soil factors. A possible disadvantage of the black box approach caused by complete soil sterilization is that, besides pathogens and parasites, the free-living soil organisms and plant mutualists have been eliminated.

It has been discussed previously that $\mathrm{N}$-fixing microbes are not supposed to contribute substantially to growth of A. arenaria (Van der Putten et al. 1988). However, arbuscular mycorrhizal fungi (AMF), which may affect both the nutrient supply as well as the plantpathogen interactions (Dehne 1982, Ernst et al. 1984, Little and Maun 1996) should be considered as an essential component of the soil biota (Koske and Halvorson 1981). Soil sterilization may cause a nutrient flush (De Nooij et al. 1986), and although this effect is quite moderate for poor dune soils, we usually supply nutrients to compensate for the potential difference in nutrients. This fertilization might have prevented AMF from becoming established; however, even when unfertilized, A. arenaria performed worse in unsterilized than in sterilized soil. Thus, even when considering that the effects measured will be the result of pathogens and mutualists, the net effect of the pathogens apparently dominated within the temporal limitations of this experiment. This might not necessarily be the case with an undisturbed arbucular mycorrhizal hyphed network.

The experiments were started by planting 2-wk-old seedlings. Under field conditions, A. arenaria and $F$. rubra seldom occur as seedlings, more usually expanding vegetatively (Huiskes 1977). As in other clonal plants, e.g., Carex arenaria (Noble et al. 1979, Tietema 1981), A. arenaria shows distinct phases of development, generally described as colonization, optimal growth, postoptimal growth, and degeneration (Huiskes 1979). In the field, $F$. rubra invades $A$. arenaria where the annual sand deposition is $<20 \mathrm{~cm} / \mathrm{yr}$, and the vigor of $A$. arenaria has become post-optimal (Anderson and Taylor 1979, Huiskes 1979). As degeneration of $A$. arenaria occurs in both the presence and absence of natural successors, interspecific competition will not be the immediate cause of degeneration (HopeSimpson and Jefferies 1966). A combination of reduced physiological activity (Yuan et al. 1993, Seliskar 1994) and intensified exposure to soil-borne pathogens (Van der Putten et al. 1988, De Rooij-Van der Goes et al. $1995 b$, Little and Maun 1996) is the most probable explanation of degeneration of both European and American Ammophila sp. Species replacement, however, may be enhanced by interspecific competition, especially when the predecessors' fitness is reduced by specific pathogens. As in the present study the seedlings were first faced with growth reduction due to soil pathogens and then with competing plant species, the order of events in the field and greenhouse appears to be the same. In further studies the gap between greenhouse and field may be bridged, e.g., by excluding soil organisms by biocides as was done by Brown and Gange $(1989,1992)$ for soil insects and by Gange et al. (1993) and Newsham et al. (1994) for AMF.

An important prerequisite for the involvement of pathogens in plant competition will be their specificity. The specificity of soil pathosystems from successional foredune plants, although demonstrated by bioassays (Van der Putten et al. 1993) has not yet been elucidated. In both $H$. rhamnoides and $A$. arenaria, a number of plant parasitic nematodes and plant pathogenic fungi may be involved (Zoon et al. 1993, De Rooij-Van der Goes et al. 1995a). The competition experiments showed that sedentary endoparasitic nematodes (Heterodera avenae group) may contribute to the specificity of the pathosystem, as they formed cysts on roots of $A$. arenaria, but not on F. rubra. Data on fungi collected from the soil showed that some species were specific for either A. arenaria or F. rubra. However, as root-inhabiting fungi were not included in the present survey, the picture may be incomplete as far as the fungi are concerned.

According to our knowledge, this is the first example where soil-borne pathogens in natural vegetation have been shown to reduce the competitive ability of their host, therefore benefiting successional plant species. Data on the occurrence of soil-borne diseases in other ecosystems are still scarce. In old fields, Bever (1994) could not demonstrate an effect of host-specific soilborne pathogens on interspecific plant competition. Further studies are therefore needed to investigate whether the results from coastal foredunes also apply to other ecosystems.

If soil-borne pathocomplexes occur more generally than has been assumed thus far, they may be involved in affecting both composition and diversity of species in natural vegetation, as was shown for other adverse soil organisms, such as insects (Brown and Gange 1989, 1990, 1992). Taking into account that interactions between plant species may be caused indirectly, via other plant species (Miller 1994), soil-borne pathogens may either enhance or reduce indirect competitive interactions. Further elucidation of the role of soilborne pathogens in the regulation of intra- and interspecific processes and considering their interactions with other (soil) biota will, therefore, be a challenge for ecological studies.

ACKNOWLEDGMENTS

We wish to thank Hoyin Wong and Wim Verveen for assistance during the experiments, Petra de Rooij-Van der Goes 
for identifying fungi and nematodes, and Sep Troelstra, Jan Woldendorp, and Justin Clapp for critically reading the manuscript. We thank Thomas E. Miller for his critical review of an earlier version of the manuscript. This is NIOO Publication 2207.

\section{Literature Cited}

Anderson, C., and K. Taylor. 1979. Some factors affecting the growth of two populations of Festuca rubra var. arenaria on the dunes of Blakeney Point, Norfolk. Pages 129-143 in R. L. Jefferies and A. J. Davy, editors. Ecological processes in coastal environments. Blackwell Scientific, London, UK.

Augspurger, C. K. 1989. Impact of pathogens on natural plant populations. Pages 413-433 in A. J. Davy, M. J. Hutchings, and A. R. Watkinson, editors. Plant population ecology. Blackwell Scientific, Oxford, UK

1990. Spatial patterns in damping-off disease during seedling recruitment in tropical forests. Pages 131-144 in J. J. Burdon and R. Leather, editors. Pest, pathogens, and plant communities. Blackwell Scientific, Oxford, UK.

Bever, J. D. 1994. Feedback between plants and their soil communities in an old field community. Ecology 75:19651977.

Bongers, T. 1988. De nematoden van Nederland. Stichting uitgeverij Koninklijke Nederlandse Natuurhistorische Vereniging, Utrecht, The Netherlands.

Brown, V. K., and A. C. Gange. 1989. Root herbivory by insects depresses plant species richness. Functional Ecology 3:667-671.

Brown, V. K., and A. C. Gange. 1990. Insect herbivory below ground. Advances in Ecological Research 20:1-58.

Brown, V. K., and A. C. Gange. 1992. Secondary plant succession: how is it modified by insect herbivory? Vegetatio 101:3-13.

Burdon, J. J. 1982. The effect of fungal pathogens on plant communities. Pages 99-112 in E. I. Newman, editor. The plant community as a working mechanism. Blackwell Scientific, Oxford, UK.

1987. Diseases and plant population biology. Cambridge University Press, Cambridge, UK.

Burdon, J. J., R. H. Groves, P. E. Kaye, and S. S. Speer. 1984. Competition in mixtures of susceptible and resistant genotypes of Chondrilla juncea differently infected with rust. Oecologia 64:199-203.

Castello, J. D., D. J. Leopold, and P. J. Smallidge. 1995 Pathogens, patterns, and processes in forest ecosystems. BioScience 45:16-24.

Chen, J., G. W. Bird, and K. A. Renner. 1995. Influence of Heterodera glycines on interspecific competition associated with Glycine max and Chenopodium album. Journal of Nematology 27:63-69.

Clay, K. 1990. The impact of parasitic and mutualistic fungi on competitive interactions among plants. Pages 391-412 in J. B. Grace and D. Tilman, editors. Perspectives on plant competition. Academic Press, San Diego, California, USA.

Clements, F. E. 1928. Plant succession and indicators. H. W. Wilson, New York, New York, USA.

Connell, J. K. 1990. Apparent versus "real" competition in plants. Pages 9-26 in J. B. Grace and D. Tilman, editors. Perspectives on plant competition. Academic Press, San Diego, California, USA.

Crawley, M. J. 1993. Succeeding in the sand dunes. Nature 362:17-18

Dehne, H. W. 1982. Interaction between vesicular-arbuscular mycorrhizal fungi and plant pathogens. Phytopathology 72:1115-1119.

De Nooij, M. P. 1987. On disease in natural populations of Plantago lanceolata. Dissertation. Utrecht University, Utrecht, The Netherlands.

De Nooij, M. P., S. R. Troelstra, and R. Wagenaar. 1986
Growth reduction in Plantago lanceolata in relation to biotic factors in the soil environment. Oecologia (Berlin) 70: 166-272.

De Rooij-Van der Goes, P. C. E. M. 1995. The role of plantparasitic nematodes and soil-borne fungi in the decline of Ammophila arenaria L. Link. New Phytologist 129:661669.

De Rooij-Van der Goes, P. C. E. M., W. H. Van der Putten, and C. Van Dijk. 1995a. Analysis of nematodes and soilborne fungi from Ammophila arenaria (Marram grass) in Dutch coastal foredunes by multivariate techniques. European Journal of Plant Pathology 101:149-162.

De Rooij-Van der Goes, P. C. E. M., W. H. Van der Putten, and B. A. M. Peters. 1995b. Effects of sand deposition on the interaction between Ammophila arenaria, plant parasitic nematodes and pathogenic fungi. Canadian Journal of Botany 73:1141-1150.

De Wit, C. T. 1960. On competition. Verslag Landbouwkundig Onderzoek 66:1-82.

De Wit, C. T., and J. P. Van den Bergh. 1965. Competition between herbage plants. Netherlands Journal of Agricultural Science 13:212-221.

Dobson, A., and M. J. Crawly. 1994. Pathogens and the structure of plant communities. Trends in Ecology and Evolution 9:393-398.

Domsch, K. H., W. Gams, and T.-H. Anderson. 1980. Compendium of soil fungi. Volumes 1 and 2. Academic Press, London, UK.

Ernst, W. H. O., W. E. Van Duin, and G. T. Oolbekking. 1984. Vesicular-arbuscular mycorrhiza in dune vegetation. Acta Botanica Neerlandica 33:151-160.

Firbank, L. G., and A. R. Watkinson. 1985. On the analysis of competition within two-species mixtures of plants. Journal of Applied Ecology 22:503-517.

Gams, W., and W. Van Laar. 1982. The use of Solacol (validamycin) as a growth retardant in the isolation of fungi. Netherlands Journal of Plant Pathology 88:39-45.

Gange, A. C., V. K. Brown, and G. S. Sinclair. 1993. Vesicular-arbuscular mycorrhizal fungi: a determinant of plant community structure in early succession. Functional Ecology 7:616-622.

Grace, J. B., and D. Tilman. 1990. Perspectives on plant competition. Academic Press, San Diego, California, USA.

Hewitt, E. J. 1966. Sand and water culture methods used in the study of plant nutrition. CAB Bureaux, Farnham Royal, UK.

Holt, R. D. 1977. Predation, apparent competition, and the structure of prey communities. Theoretical Population Biology 12:197-229.

- 1984. Spatial heterogeneity, indirect interactions, and the coexistence of prey species. American Naturalist 124:377-406

Hope-Simpson, J. F., and R. L. Jefferies. 1966. Observations relating to vigour and debility in marram grass (Ammophila arenaria (L.) Link). Journal of Ecology 54:271-275.

Huiskes, A. H. L. 1977. The natural establishment of Ammophila arenaria from seed. Oikos 29:133-136.

. 1979. Biological flora of the British isles: Ammophila arenaria (L.) Link (Psamma arenaria (L.) Roem. et Schult.: Calamagrostis arenaria (L.) Roth). Journal of Ecology 67:363-382.

Inouye, R. S., and W. M. Schaffer. 1981. On the ecological meaning of ratio (de Wit) diagrams in plant ecology. Ecology 62:1679-1681.

Jarosz, A. M., and A. L. Davelos. 1995. Effects of disease in wild plant populations and evolution of pathogen aggressiveness. New Phytologist 129:371-387.

Koske, R. E., and W. L. Halvorson. 1981. Ecological studies of vesicular-arbuscular mycorrhizae in a barrier sand dune. Canadian Journal of Botany 59:1413-1422. 
Linders, E. G. A. 1994. On the interactions between a wild host plant, a fungal pathogen and an insect herbivore. Dissertation. University of Utrecht, Utrecht, The Netherlands.

Little, L. R., and M. A. Maun. 1996. The "Ammophila problem" revisited: a role for mycorrhizal fungi. Journal of Ecology 84:1-7.

Louda, S. M., K. H. Keeler, and R. D. Holt. 1990. Herbivore influences on plant performance and competitive interactions. Pages 414-444 in J. B. Grace and D. Tilman, editors Perspectives on plant competition. Academic Press, San Diego, California, USA.

Marshall, J. K. 1965. Corynephorus canescens (L.) P. Beauv. as a model for the Ammophila problem. Journal of Ecology 53:447-465.

Miller, T. E. 1994. Direct and indirect species interactions in an early old field plant community. American Naturalist 143: $1007-1025$.

Nelson, P. E., T. A. Toussoun, and W. F. O. Marasas. 1983. Fusarium species. An illustrated manual for identification. Pennsylvania State University Press, State College, Pennsylvania, USA.

Newsham, K. K., A. H. Fitter, and A. R. Watkinson. 1994 Root pathogenic and arbuscular mycorrhizal fungi determine fecundity of asymptomatic plants in the field. Journal of Ecology 82:805-814.

Noble, J. C., A. D. Bell, and J. L. Harper. 1979. The population biology of plants with clonal growth. I. The morphology and structural demography of Carex arenaria. Journal of Ecology 67:983-1008.

Olff, H., J. Huisman, and B. F. Van Tooren. 1993. Species dynamics and nutrient accumulation during early primary succession in coastal sand dunes. Journal of Ecology 81: 693-706.

Oostenbrink, M. 1960. Estimating nematode populations by some selected methods. Pages 85-102 in J. N. Sasser and W. R. Jenkins, editors. Nematology. University of North Carolina Press, Chapel Hill, North Carolina, USA.

Oremus, P. A. I., and H. Otten. 1981. Factors affecting growth and nodulation of Hippophaë rhamnoides in soils from two successional stages of dune formation. Plant and Soil 63:317-331.

Paul, N. D. 1989. The effects of Puccinia lagenophorae on Senecio vulgaris in competition with Euphorbia peplus. Journal of Ecology 77:552-564.

Ranwell, D. S. 1958. Movement of vegetated sand dunes at Newborough Warren, Anglesey. Journal of Ecology 46:83100

Seliskar, D. M. 1994. The effects of accelerated sand accre- tion on growth, carbohydrate reserves, and ethylene production in Ammophila breviligulata (Poaceae). American Journal of Botany 81:536-541.

's Jacob, J. J., and J. Van Bezooijen. 1984. Manual for practical work in nematology. Department of Nematology, Agricultural University, Wageningen, The Netherlands.

Snaydon, R. W. 1994. Replacement and additive designs revisited: comments on the review paper by N. R. Sackville Hamilton. Journal of Applied Ecology 31:784-786.

Sokal, R. R., and F. J. Rohlf. 1981. Biometry. The principles and practices of statistics in biological research. W. H. Freeman, New York, New York, USA.

Tietema, T. 1981. Ecophysiology of the sand sedge, Carex arenaria L. Dissertation. University of Utrecht, Utrecht, The Netherlands.

Tilman, D. 1982. Resource competition and community structure. Princeton University Press, Princeton, New Jersey, USA.

Van der Putten, W. H., P. W. Th. Maas, W. J. M. Van Gulik, and H. Brinkman. 1990. Characterization of soil organisms involved in the degeneration of Ammophila arenaria. Soil Biology and Biochemistry 22:845-852.

Van der Putten, W. H., and S. R. Troelstra. 1990. Harmful soil organisms in coastal foredunes involved in degeneration of Ammophila arenaria and Calammophila baltica. Canadian Journal of Botany 68:1560-1568.

Van der Putten, W. H., J. T. Van der Werf-Klein Breteler, and C. Van Dijk. 1989. Colonization of the root zone of Ammophila arenaria by harmful soil organisms. Plant and Soil 120:213-223.

Van der Putten, W. H., C. Van Dijk, and B. A. M. Peters. 1993. Plant-specific soil-borne diseases contribute to succession in foredune vegetation. Nature 362:53-56.

Van der Putten, W. H., C. Van Dijk, and S. R. Troelstra. 1988. Biotic soil factors affecting the growth and development of Ammophila arenaria. Oecologia 76:313-320.

Willis, A. J. 1989. Coastal sand dunes as biological systems. Proceedings of the Royal Society of Edinburgh 96B:1736.

Yuan, T., M. A. Maun, and W. G. Hopkins. 1993. Effects of sand accretion on photosynthesis, leaf-water potential and morphology of two dune grasses. Functional Ecology 7: 676-682.

Zoon, F. C., S. R. Troelstra, and P. W. Th. Maas. 1993. Ecology of the plant-feeding nematode fauna associated with sea buckthorn (Hippophaë rhamnoides L. ssp. rhamnoides) in different stages of dune succession. Fundamental and Applied Nematology 16:247-258. 